\title{
ANGIE $\mid$ Beyond Anthropocentrism: Cosmopolitanism and Nonhuman Animals
}

\begin{abstract}
All cosmopolitan approaches to global distributive justice are premised on the idea that humans are the primary units of moral concern. In this paper, I argue that neither relational nor non-relational cosmopolitans can unquestioningly assume the moral primacy of humans. Furthermore, I argue that, by their own lights, cosmopolitans must extend the scope of justice to most, if not all, nonhuman animals. To demonstrate that cosmopolitans cannot simply 'add nonhuman animals and stir,' I examine the cosmopolitan position developed by Martha Nussbaum in Frontiers of Justice. I argue that while Nussbaum explicitly includes nonhuman animals within the scope of justice, her account is marked by an unjustifiable anthropocentric bias. I ultimately conclude that we must radically reconceptualise the primary unit of cosmopolitan moral concern to encompass most, if not all, sentient animals.
\end{abstract}

Keywords: Global justice; cosmopolitanism; nonhuman animals; sentience; relational and non-relational; capabilities approach

\section{Introduction}

All cosmopolitan approaches to global distributive justice are premised on the notion that individuals are the primary units of moral concern. Specifically, most mainstream cosmopolitans consider these individuals to be genetically human. That is to say, cosmopolitans tend to view only humans as the proper subjects of justice and deal only with justice as it applies to inter-human relationships. However, as I will demonstrate, the omission of nonhuman animals from cosmopolitan theorising about justice is yet to be justified; thus, it represents a significant and challenging shortfall in prevailing cosmopolitan approaches. ${ }^{1}$

Broadly speaking, cosmopolitan approaches to distributive justice can be divided into two camps: relational and non-relational. ${ }^{2}$ On the one hand, relational cosmopolitans ground claims of justice in features of relationships, associations and shared institutions. ${ }^{3}$ On the other hand, non-relational

1 My focus throughout this paper is on sentient nonhuman animals, that is, nonhuman animals with the capacity to feel, to experience and to have subjective states of awareness.

2 Andrea Sangiovanni, 'Global justice, Reciprocity, and the State', Philosophy and Public Affairs 35/1 (2007), 3-39, pp. 5-8.

3 See, for example, Charles Beitz, 'Justice and International Relations', Philosophy and Public Affairs 4/4 (1975), 360-389; Charles Beitz, Political Theory and International Relations (2nd ed.) (Princeton, NJ: Princeton University Press, 1999); Thomas Pogge, Realizing Rawls (Ithaca: Cornell University Press, 1989); Thomas Pogge, World Poverty and Human Rights (2nd ed.) (Oxford: Polity, 2008); Darrel Moellendorf, Cosmopolitan Justice (Boulder: Westview Press, 2002); Darrel Moellendorf, 'Human Dignity, Associative Duties, and Egalitarian Global Justice', in Gillian Brock (ed.), Cosmopolitanism versus Non-Cosmopolitanism: Critiques, Defenses, Reconceptualizations (Oxford: Oxford University Press, 2013), 222-238. 
cosmopolitans ground claims of justice in humanity itself. ${ }^{4}$ In this paper, I draw two conclusions regarding cosmopolitan approaches to global justice. First, neither relational nor non-relational cosmopolitans can exclude all nonhuman animals from the scope of justice without first justifying the assumption that only humans are the proper subjects of global justice. Second, in the absence of arguments to the contrary, there are good reasons to think that both relational and non-relational cosmopolitans must include at least a significant number of nonhuman animals within the scope of cosmopolitan justice.

The paper is structured as follows. I begin by outlining the central tenets of cosmopolitan approaches to questions of distributive justice. Next, I argue that possessing the capacity for well-being is sufficient for an individual to qualify as a potential subject of cosmopolitan justice. I then offer three interconnected reasons to support the claim that relational cosmopolitans must consider a significant number of nonhuman animals as actual subjects of justice: first, both human and nonhuman animals compete for the Earth's scarce resources and are subject to existing distributional schemes; second, nonhuman animals cooperate in and contribute to global schemes of interaction; and third, many nonhuman animals' lives are heavily influenced by human institutions at the global level. I then argue that advocates of non-relational cosmopolitanism cannot, without further argument, discount nonhuman animals as proper subjects of justice. Furthermore, by extending a core cosmopolitan intuition, I suggest that just as an individual's sex, race, class, physical attributes, conception of the good and place of birth should not affect their status as an equal unit of moral concern, neither should species membership.

Having argued that cosmopolitans of all stripes must regard at least a significant number of nonhuman animals as subjects of justice, I consider one of the few cosmopolitan accounts to directly address the well-being of nonhuman animals, namely, Martha Nussbaum's capabilities approach. ${ }^{5}$ I argue that Nussbaum's account is deeply conflicted and is underpinned by a morally problematic anthropocentrism. I ultimately conclude that cosmopolitan approaches to global justice will continue to be inadequate unless the cosmopolitan 'individual' represents not just those animals who are human but also some who are not.

4 See, for example, Brian Barry, 'International Society from a Cosmopolitan Perspective' in D. Mapel \& T. Nardin (eds.), International Society: Diverse Ethical Perspectives (Princeton: Princeton University Press, 1998), 144-161; Brian Barry, 'Statism and Nationalism: A Cosmopolitan Critique' in I. Shapiro \& L. Brilmayer (eds.), Global Justice, NOMOS (New York: New York University Press, 1999), 12-66; Simon Caney, Justice Beyond Borders: A Global Political Theory (Oxford: Oxford University Press, 2005); Simon Caney, 'Cosmopolitanism and Justice' in Thomas Christiano and John Christman (eds.), Contemporary Debates in Political Philosophy (Oxford: Wiley-Blackwell, 2009), 387-407; Martha Nussbaum, Frontiers of Justice: Disability, Nationality, Species Membership (Cambridge, MA: Harvard University Press, 2006).

5 Nussbaum (2006). 


\section{BEYOND ANTHROPOCENTRISM: COSMOPOLITANISM AND NONHUMAN ANIMALS}

\section{Cosmopolitan Justice}

The distinctive feature of cosmopolitan accounts of justice is that the sphere of justice is global in scope. Motivated by the extensive and egregious material inequality that exists between individuals across the globe today, cosmopolitans argue that justice demands that we consider our responsibilities to human beings globally. This involves considering the moral, political, legal and economic entitlements and duties that every human being possesses as a matter of justice. Moreover, it is an issue of distributive justice. Cosmopolitans ask us to think about the inequalities in our world and consider whether the current allocation of resources, opportunities, rights, freedoms, and other goods is just.

While there are various cosmopolitan approaches which address questions of global justice, they all embody the foundational tenets of moral cosmopolitanism: individuals are the primary units of moral concern, all individuals enjoy this status equally, and having this status generates obligations that are binding on all. ${ }^{6}$ Therefore, a commitment to moral cosmopolitanism entails considering individuals as the primary units of equal moral concern, which requires giving every individual in the world equal respect and consideration in deliberations of justice, irrespective of where they live or what other affiliations they might have. ${ }^{7}$ Moreover, the needs, interests, and well-being of individuals are given moral priority over those of groups, communities, and nation-states.

Despite its admirable aims, I contend that most contemporary cosmopolitan approaches to global distributive justice are problematically anthropocentric because they assume the priority of human needs and interests while ignoring the needs and interests of all other animals. This bias towards human need renders the cosmopolitan 'individual' always and only human. ${ }^{8}$ Thus, humans are at the centre of the cosmopolitan universe, and human interests are weighted accordingly: above the interests of all other animals, which are often afforded no weight at all.

\section{Can Animals Be Recipients of Cosmopolitan Justice?}

One might argue that cosmopolitan accounts are not problematically anthropocentric because nonhuman animals cannot be recipients of justice. ${ }^{9}$

6 Thomas Pogge, 'Cosmopolitanism and Sovereignty', Ethics 103/1, 48-75 (1992), pp. 48-49.

7 To say that 'individuals are the primary units of moral concern' in cosmopolitan accounts of justice is to hold that individuals are the 'primary subjects of justice' in a cosmopolitan framework. Therefore, I use these two phrases interchangeably throughout the paper.

8 Simon Caney briefly suggests that, when formulating a theory of justice, we might consider whether all sentient creatures are to be regarded as members of a scheme of distributive justice; however, he swiftly moves on to assume that only human persons matter (2005, pp. 103-105).

9 I am assuming that the capacity to fulfil duties of justice is not a necessary condition for being considered a recipient of justice. Most, if not all, cosmopolitans grant infant humans entitlements as a matter of justice even though they cannot take responsibility within schemes of cosmopolitan justice. 
To counter this response, I argue in this section that all sentient animals qualify as candidate recipients of cosmopolitan justice. While the following remarks will not be compatible with all existing views about the nature of justice, it is important to remember that I am only concerned with a particular family of views: namely, those that fall under the umbrella of liberal cosmopolitanism. Therefore, I consider the following remarks to represent a set of widely shared assumptions in cosmopolitan theorising.

While justice can be about many things, two of its features are commonly accepted. First, duties and entitlements of justice are enforceable, and those who evade their obligations can be legitimately coerced or sanctioned for their failure to comply. In contrast, one cannot be compelled to fulfil moral duties of charity or compassion, irrespective of how morally demanding such duties might be. Second, justice is the domain of rightful entitlement. States of affairs are described as just when all subjects of justice have received what they are entitled to; individuals are treated justly when they receive their due. In contrast, states of affairs are unjust when subjects of justice have not received their rightful entitlements.

But who can be considered a primary subject of cosmopolitan justice? That is, which individuals can be appropriately assigned entitlements and duties of cosmopolitan justice? Here, I want to suggest that one central function of justice is to ensure and promote individual well-being. ${ }^{10}$ Thus, one reason justice matters morally is that injustice, by denying us our rightful entitlements, sets back our interests. For example, if gross inequality in resources results in the inability of some individuals to meet their basic needs while others benefit from their disadvantage, cosmopolitans tend to view this situation as unjust. This inequality is not only unfair but also unjust because those who cannot meet their basic needs are deprived of well-being. Although autonomy, equality, fairness, rights, institutions, the distribution of resources, and access to opportunities, among many other things, are undoubtedly relevant to considerations of justice, these often only matter to us insofar as they are important to individual wellbeing.

If a central role of cosmopolitan justice is to protect and promote individual well-being, all individuals with the capacity for well-being must matter from the perspective of justice because their interests potentially generate entitlements. Note, however, that while an individual with the capacity for well-being is a candidate for just entitlements, further argument regarding the grounds of

10 Cosmopolitans define well-being in different ways, but regardless of how an approach articulates a conception of individual well-being - be it in terms of capabilities, rights, interests, or something else - 'cosmopolitan liberalism takes the well-being of individuals as fundamental' (Charles Beitz, 'Social and Cosmopolitan Liberalism', International Affairs, 75/3 (1999), 515-529, p. 520). 


\section{BEYOND ANTHROPOCENTRISM: COSMOPOLITANISM AND NONHUMAN ANIMALS}

justice might subsequently exclude that individual from a particular scheme of justice. ${ }^{11}$ One might argue, for example, that a discrete set of duties and entitlements of justice arise only between individuals interacting with one another in a scheme of cooperation. However, candidate subjects of justice cannot simply be disregarded out of hand, and any attempt to exclude them from the remit of a particular scheme must be justified. Furthermore, this justification must adequately explain why some individuals are recipients in a scheme of justice while others are not, and it must do so in morally nonarbitrary ways.

Importantly, the capacity for well-being is not unique to humans. All sentient animals are subjectively aware, have emotional experiences, and possess the capacity to feel pleasure and pain; thus, when their lives go badly, they go badly for them. Since each sentient animal's quality of life is affected when their interests are set back, they can be properly understood as having the capacity for well-being, which is to say, they have lives that can go more or less well. ${ }^{12}$ Whether an individual's life does in fact go well depends upon whether their fundamental interests - in adequate nutrition, clean water, security, not being exploited, not experiencing suffering, and having the opportunity to form attachments, for example - are served or set back.

The fact that both human and nonhuman animal lives can go badly when our fundamental interests are not satisfied qualifies us all as potential entitlementbearers in schemes of distributive justice. Of course, different sentient animals' entitlements will be shaped by their distinctive interests. For example, some dolphins have an interest in unpolluted saltwater as it enables them to survive and enjoy good bodily health; some humans have an interest in freedom of speech as it enables them to exercise their political agency and autonomy; and working dogs have an interest in non-exploitative labour conditions, which are necessary for a well-balanced life. However, importantly, while different interests may ground different entitlements, these differences do not affect the basic status of all sentient animals as potential entitlement-bearers in schemes of justice. ${ }^{13}$

11 Later in this paper, I evaluate relational cosmopolitan approaches to global justice, which ground some duties and entitlements of justice in certain forms of global relationships. According to those views, only humans who stand in a particular relationship with other humans count as actual subjects of cosmopolitan justice.

12 Crucially, since plants and inanimate objects are not sentient, they neither have the capacity for well-being nor any interests that affect well-being. The reason for this, according to Alasdair Cochrane, is that 'states of affairs improve or deteriorate such things as plants, but lacking conscious life, no state of affairs can actually make things better or worse for plants themselves' (2012, p. 38). Hence, although there may be other reasons for attributing moral standing to non-sentient entities, here I assume that having the capacity for sentience is a necessary prerequisite for being admitted to the sphere of justice because justice involves the fair distribution of resources to satisfy interests and general well-being. Since plants have neither well-being nor interests, they cannot be recipients of justice.

13 The threshold for well-being in different sentient animals will vary greatly depending not just on individual heterogeneity but also on the kind of creature they are. I cannot here specify what this means for the precise content of our duties or their stringency because the magnitude of that task goes beyond the scope of this paper. Nor can I elaborate on how we are to resolve conflict between the fundamental interests of different sentient animals. However, answering these questions will be key in developing a comprehensive account of sentience-centred cosmopolitanism. 
In the following sections, I argue that the logic of cosmopolitanism demands that most, if not all, nonhuman animals must be included as actual entitlementbearers within schemes of cosmopolitan justice.

\section{Relational and Non-Relational Cosmopolitanism: Global Injustice and the Use and Abuse of Nonhuman Animals}

As mentioned above, contemporary cosmopolitan approaches to global justice can, broadly speaking, be divided into two camps: relational and non-relational. In this section, I argue that both relational and non-relational cosmopolitans must, by their own lights, reconceptualise the cosmopolitan individual to encompass at least some sentient animals.

\section{Relational Cosmopolitanism}

Relational conceptions of distributive justice maintain 'that the practicemediated relations in which individuals stand condition the content, scope, and justification of those principles. ${ }^{14}$ In essence, duties of justice are grounded in features of relationships, associations and shared institutions, and depend on the existence of such relationships. To illustrate, consider Thomas Pogge's relational cosmopolitanism. Crucial to Pogge's view is the claim that citizens and governments of prosperous countries impose a 'global institutional order that foreseeably and avoidably reproduces severe and widespread poverty. ${ }^{15}$ Thus, for Pogge, the existence of global institutional relationships generates a negative cosmopolitan duty of justice not to participate in, or maintain, institutional arrangements that harm others.

Pogge focuses on poverty because it causes immense suffering globally and is responsible for the premature death of millions of humans each year. ${ }^{16}$ Yet, why should only human interests be considered here? If we concede that nonhuman animals also have lives that can go more or less well, then the relational cosmopolitan must surely consider rectifying human institutions that cause suffering and premature death to both human and nonhuman animals alike. I anticipate that many relational cosmopolitans will want to resist the extension of their theories to nonhuman animals; therefore, in what immediately follows, I explain why such resistance would be inconsistent with their other commitments. ${ }^{17}$

4 Sangiovanni (2007), p. 5.

5 Pogge (2008), p. 207.

16 Ibid., p. 104.

17 My aim here is to suggest that relational cosmopolitans cannot uncritically assume that nonhuman animals fall outside the domain of justice. The reasons I present are not intended as an exhaustive discussion of why relational theorists in general need to extend their theories to nonhuman animals. More detailed accounts of why relational or 'associative' accounts of justice must extend to human/nonhuman animal relationships can be found in the following: Mark Coeckelbergh, 'Distributive Justice and Co-Operation in a World of Humans and Nonhumans: A Contractarian Argument for Drawing Nonhumans into the Sphere of Justice', Res Publica 15/1 (2009), 67-84; Sue Donaldson and Will Kymlicka, Zoopolis: A Political Theory of Animal Rights (Oxford: Oxford University Press, 2011); and Laura Valentini, ‘Canine Justice: An Associative Account', Political Studies 62/1 (2014), 37-52. 


\section{BEYOND ANTHROPOCENTRISM: COSMOPOLITANISM AND NONHUMAN ANIMALS}

First, relational cosmopolitans argue that the current distribution of resources at the global level is unjust and that much of the human misery and suffering associated with global poverty is perpetrated by the existing global institutional order. ${ }^{18}$ Furthermore, relational cosmopolitans contend that sufficient resources exist to ensure that all humans live a life free from the misery and suffering associated with poverty, and thus we have a duty to establish institutional arrangements that have just distributive outcomes.

However, the existing distribution of resources does not only affect human lives. Since nonhuman animals also have the capacity for well-being, they too can suffer terribly when resources are distributed in ways that set back their fundamental interests. Consider, for example, the fact that both human and nonhuman animals need access to safe drinking water. In March 2014, the Government of Casanare, Columbia, announced that over 20,000 animals died due to a severe drought that was undoubtedly exacerbated by human activity, including deforestation, cattle farming, oil extraction, and climate change. ${ }^{19}$ Similarly, humans and the domesticated animals with whom they share their homes and political communities are equally vulnerable to hunger when crops fail and food prices are too high. ${ }^{20}$ Furthermore, some domesticated animals are doubly burdened by the global distribution of resources when they themselves are regarded as resources to be bought, sold, killed, and consumed in order to alleviate human poverty in certain regions. ${ }^{21}$

It is often assumed that ideas of justice pertain only to human relations, but when humans exploit and destroy the Earth's natural resources in ways that harm nonhuman animals it is difficult to see why humans alone have an absolute right to those resources, and why the harm humans do to other animals through their unbridled and often irresponsible use of those resources is neutral from the perspective of distributive justice. Importantly, satisfying many animal interests (including those of human animals) requires valuable resources resources that are moderately scarce. Given this brute fact about the lives of all animals, it is deeply problematic for relational cosmopolitans to consider only humans as the primary units of moral concern. If we are concerned with the

18 Thomas Pogge, 'The Role of International Law in Reproducing Massive Poverty', in S. Besson \& J. Tasioulas (eds.), The Philosophy of International Law (Oxford: Oxford University Press, 2010), pp. 417-435.

19 More information can be found on the Government of Casanare's official website <http://www.casanare.gov. co/?idcategoria $=30825>$ (Accessed: 8 November 2016).

20 Domestication raises many complicated issues of interspecies justice, and justice might demand that some processes of domestication be eliminated, including raising and killing animals for meat and dairy products. For a nuanced account of the complex array of interspecies relationships and how they affect what we owe to our fellow sentient beings, see Donaldson and Kymlicka (2011).

21 For example, the FAO reports positively on the 'booming' success of Somalia, which exported five million livestock to markets in the Gulf of Arabia in 2014 (http://www.fao.org/news/story/en/item/283777/icode/ (Accessed: 8 November 2016). The boost in Somalia's livestock export industry is a result of support and financing from the FAO, EU and UK. While this is viewed as economic success for Somalia and a means of reducing the 'vulnerability of rural households,' the vulnerability of the livestock animals is not considered - apart from their vulnerability to disease, which threatens or lowers their value as commodities. 
ways in which existing distribution patterns undermine the well-being of some individuals to the benefit of others, then we must include nonhuman animals in our thinking about global justice since they are also affected by unbalanced resource distribution.

The second reason that some relational cosmopolitans give to justify extending the scope of justice beyond national boundaries is that the high degree of socioeconomic and political interdependence at the global level constitutes a global scheme of social cooperation. ${ }^{22}$ The thought here is that, similar to the domestic sphere, the global sphere is justice-apt because all humans are interlocked in a global cooperative scheme. However, if relations of interdependence and cooperation generate duties and entitlements of justice, then it is far from obvious why the only interaction that counts is that which takes place between human animals. Here I argue that nonhuman animals often also stand in the correct justice-grounding relationship to humans through their contribution to schemes of global cooperation. ${ }^{23}$

Nonhuman animals cooperate with humans and contribute to schemes of interspecies activity in many ways. For example, they have served in the military, in the police force, in rescue services, in mining, in logging, as messengers, as means of transport for humans and their things, as assistants to humans with disabilities, as human entertainment, as companions, and many have contributed their lives to satisfy human desires for, amongst many other things, their hair, their skin, and their flesh. Importantly, in our globalising world, the ways in which nonhuman animals contribute in one particular geographical location often influences human and nonhuman animal lives elsewhere. We only have to think about global trades in exotic pets, meat, fur, and skin or the use of animals in medical research to see that this is true. It is, therefore, difficult to justify the claim that nonhuman animals do not have justice-based entitlements on the grounds that they do not contribute in global schemes of cooperation.

Third, and finally, relational cosmopolitans argue that principles of justice are required to regulate institutions at the global level because of the basic global structure's profound effects on the life prospects of individuals globally. ${ }^{24}$ This is analogous to the argument for domestic justice, most famously advanced by

22 Beitz (1999), pp. 143-153. The view that I outline here is more representative of Beitz's early position. In later works, Beitz appears to move away from the relational stance (e.g. Charles Beitz, 'Cosmopolitan Ideals and National Sentiment', The Journal of Philosophy 80/10 (1983), 591-600, p. 595).

23 It is important to note that on this view, many wild nonhuman animals will not be considered as recipients within a scheme of justice because they do not cooperate with humans in schemes of interaction. However, as with humans who fall outside of schemes of cooperation, they still have fundamental rights of non-interference that must be respected. I thank an anonymous reviewer for raising this point.

24 See, for example, Beitz (1999) and Pogge (2008). 


\section{BEYOND ANTHROPOCENTRISM: COSMOPOLITANISM AND NONHUMAN ANIMALS}

Rawls, that society's basic structure is the primary subject of justice because 'its effects are so profound and pervasive, and present from birth.' ${ }^{25}$ But why should we care about institutions only insofar as they affect human lives? As noted above, many nonhuman animals are a part of human interactional systems of interdependence, and the institutions that govern them affect their lives profoundly. Moreover, the matter looks particularly urgent when we consider the multitude of ways in which human institutions disregard the wellbeing of other animals, and allow billions of nonhuman animals to be captured, maimed, tortured, traumatized, exploited, and killed in order to satisfy a global demand for their bodies, body parts, or bodily secretions.

Consider, for instance, the nonhuman animals that are farmed for food - a group who arguably experience the brutality of human institutional regulation most directly. Live animals, dead animals and their body parts are increasingly being traded at the international level with over 57 billion land animals being farmed and killed for human consumption each year. ${ }^{26}$ The forecast for 2016 is that the world's major exporters will move around 9.9 million tons of cows' flesh, 10.7 million tons of chicken flesh and 7.3 million tons of pigs' flesh across national borders. ${ }^{27}$ Moreover, the consolidation of the global meat industry means that meat producers 'are getting bigger through mergers and acquisitions - expanding across borders and species. ${ }^{28}$ For example, the Brazilian company JBS is the largest meat producer (by sales) in the world with the global capacity to slaughter 85,000 cattle, 70,000 pigs and 12 million birds daily, and distribute their bodies and body parts in 150 countries. ${ }^{29}$

The global market for meat products is regulated by local, national, supranational, and international bodies and legal frameworks, which set the conditions under which nonhuman animals are kept, what they can eat and when, which illnesses they can be medicated for (or condemned for), how they are transported, and how they are slaughtered. Moreover, the raising and slaughter of animals for food is incentivised by a complex system of cash subsidies, tax exemptions, export credit guarantees, development grants, and duty free import, which are regulated nationally, regionally and internationally by bodies such as the European Union and World Trade Organization. ${ }^{30}$

25 John Rawls, A Theory of Justice, Rev. Ed. (Oxford: Oxford University Press, 1999), p. 82.

26 Gary L. Francione and Anna Charlton, Eat Like You Care - An Examination of the Morality of Eating Animals (Exempla Press, 2013), p. 2.

27 Foreign Agricultural Service/United States Department of Agriculture, Livestock and Poultry: World Markets and Trade (2015), <http://apps.fas.usda.gov/psdonline/circulars/livestock_poultry.PDF> (Accessed: 8 November 2016).

28 Heinrich Böll Stiftung, Meat Atlas: Facts and Figures About the Animals We Eat (Germany: Heinrich Böll Foundation/ Friends of the Earth Europe, 2014), p. 11.

29 Ibid., p. 11.

30 See Oscar Horta 'Expanding Global Justice: The Case for the International Protection of Animals', Global Policy 4/4 (2013), 371-380. Horta explains how animal industries are protected internationally and argues for the establishment of international organisations to protect animal rights as a matter of global justice. My argument here complements Horta's conclusions by offering an internal critique of cosmopolitan approaches to global justice. 
In addition to trade that is currently recognised as legal, a growing global black market is active in live and dead animals, animal body parts, and animal products. Due to the market's illicit nature, the exact value of the illegal trade in nonhuman animal bodies is difficult to assess, although estimates tend to put the figure between eight and twenty billion US dollars - 'it ranks fourth on the list of the most lucrative global illegal activities closely behind drugs, counterfeiting and human trafficking. ${ }^{31}$ Moreover, the Internet has intensified the global dimension of illegally seized wildlife, and the sale of animal bodies is now increasingly conducted in the online marketplace. Over the course of six weeks in 2014, The International Fund for Animal Welfare (IFAW) monitored 280 online marketplaces in 16 different countries and found 33,006 endangered wildlife, and wildlife parts and products for sale, worth a total of US $\$ 10,708,137$. Of the adverts recorded, 54 percent and 46 percent were for the sale of live animals and animal parts and products, respectively. ${ }^{32}$ While many nongovernmental organisations fighting the illegal trade in animal bodies call for individual governments to create more robust laws to protect animals against cybercrime and their illegal seizure in the wild, there is 'general agreement among governments and international organisations that the commitments made and the actions taken are uncoordinated and fail to address the issue effectively.' 33

The existing global order undoubtedly has different impacts on the lives of different nonhuman animals, rendering some more vulnerable than others. However, there is one way in which human institutional schemes affect the lives of all animals irrespective of whether they are domesticated, wild, or human. Specifically, the existing global order exacerbates anthropogenic climate change, the consequences of which are already disastrous for some of the world's most vulnerable sentient animals. Human institutions regulate human activity and determine the appropriate limit on carbon emissions. The political gridlock that slows both policy and action on climate change illustrates one basic way in which the existing institutional framework impacts all animals. ${ }^{34}$

It should be clear by now that the lives of most, if not all, nonhuman animals are either directly regulated or at least indirectly affected by human institutions

31 International Fund for Animal Welfare, Wanted - Dead or Alive: Exposing Online Wildlife Trade (London, UK: International Fund for Animal Welfare, 2014), p. 4.

32 Ibid., p. 7.

33 World Wildlife Fund/Dalberg, Fighting Illicit Wildlife Trafficking: A Consultation With Governments. (Switzerland: WWF International, 2012), p. 5

34 Human institutions are also responsible for the increase in deforestation - a significant cause of anthropogenic climate change - caused by clear-cutting for agriculture, cattle ranching and unsustainable logging for timber. Deforestation displaces and kills millions of wild nonhuman animals annually, destroys nonhuman animal habitats and diminishes the quantity and quality of water sources that are essential to both human and nonhuman animals living in those areas. See the United Nations Environment Programme (UNEP), Global Environment Outlook: Environment for Development (GEO-4) (Nairobi, Kenya: UNEP, 2007). 


\section{BEYOND ANTHROPOCENTRISM: COSMOPOLITANISM AND NONHUMAN ANIMALS}

and regulative frameworks. Thus, if we have an interest in the regulation of the global basic structure because of the profound and pervasive effects that it has on our human lives, then it would appear that nonhuman animals also have an interest in the same end.

I take these reasons as evidence that relational cosmopolitans cannot omit, without further argument, all nonhuman animals from their theorising about global justice. To be sure, determining which nonhuman animals will count as actual entitlement-bearers will depend on the particular obligation-grounding relationships invoked to ground our duties of global justice. However, as should be clear from the above discussion, relational cosmopolitans must, at the very least, include a significant number of nonhuman animals as subjects of justice within their cosmopolitan frameworks - unless they can offer us further justification for excluding those animals.

\section{Non-Relational Cosmopolitanism}

Simon Caney's 'humanity-centered' cosmopolitanism is a paradigm example of the non-relational cosmopolitan perspective. Caney's approach is nonrelational because principles of justice are not grounded in any particular relations between persons but rather

[...] one has obligations of justice to others because they are fellow human beings - with human needs and failings, and human capacities for, and interests, in autonomy and well-being - and facts about interdependence do not, in themselves, determine the scope of distributive justice. ${ }^{35}$

Therefore, for Caney, human beings have obligations and entitlements of justice simply because they are human beings. Thus, one's entitlements are not grounded in one's relationships with others, but rather in virtue of one's humanity.

An important part of Caney's project is to draw out the full implications of our deeply held moral convictions and show how principles of global justice flow from them, and it is by this strategy that he justifies his own cosmopolitan view:

The best argument in favour of this humanity-centered conception of cosmopolitan justice starts from the observation that there is a strong conviction that persons should not fare worse in life because of morally arbitrary characteristics such as their ethnicity or their religion or their regional identity. Distributive justice, we hold, should be blind to such features of persons. [...] Now humanity-

35 Caney (2009), p. 391. 
centred cosmopolitanism adopts the same intuition and concludes that persons should not also face worse opportunities because of their nationality or their citizenship. To do so would also be to penalize people for morally arbitrary reasons. ${ }^{36}$

Moreover, Caney suggests that cosmopolitanism demands that all morally arbitrary features be ignored when determining the scope of justice. Indeed, the attractiveness of his position derives from his willingness to extend the idea that no one should be penalised on the basis of morally arbitrary circumstances to its logical conclusion. However, if Caney is correct about this, then the nonrelational cosmopolitan must defend the assumption that only humans are the proper subjects of justice and that species is morally relevant to determining the scope of justice. By uncritically assuming that only humans are the proper subjects of justice, the non-relational cosmopolitan fails to explain why we should consider the interests of just one species, among the tens of thousands that populate this planet, when determining how the world's resources ought to be distributed. This omission is all the more striking when we recall that it is not only human animals whose lives go badly when they do not have access to clean drinking water, adequate nutrition, shelter, healthcare, and a safe environment. The problem with 'humanity-centered' cosmopolitan accounts is that rarely, if ever, is an attempt made to justify the anthropocentric assumption that only humans matter in considerations of justice. If national membership is morally arbitrary, then why would we think that species membership is any different?

While some non-relational cosmopolitans may be sympathetic to my argument so far, I anticipate that not everyone will be so readily persuaded. ${ }^{37}$ Indeed, some non-relational cosmopolitans might be inclined to maintain that species is morally relevant to determining who can qualify as a recipient of justice. ${ }^{38}$ Given this potential line of response, we need to consider what might be special about humanity such that only human animals can be the proper subjects of justice.

I do not want to rehearse the debate between animal rights theorists and their opponents here. However, it is important to note that attempts to protect the status of humans as the only beings who are morally entitled to certain forms of protection and treatment have been subject to extensive criticism. One

36 Ibid., p. 394.

37 It should be noted that although Caney has not written directly on the topic of nonhuman animals, he has indicated in personal correspondence that he strongly supports the inclusion of nonhuman animals within the scope of cosmopolitan justice.

38 Cosmopolitans like Charles Beitz, Thomas Pogge and Gillian Brock, who appeal to a global original position, would further need to respond to arguments advanced by Mark Rowlands, which suggest that both rationality and species should be included within the veil of ignorance (Mark Rowlands, 'Contractarianism and Animal Rights', Journal of Applied Philosophy 14/3 (1997), 235-247). 


\section{BEYOND ANTHROPOCENTRISM: COSMOPOLITANISM AND NONHUMAN ANIMALS}

common strategy for denying animal rights, for example, relies on the thought that nonhuman animals lack some capacity or set of capacities - such as rationality or moral agency - that is morally relevant when determining which entities count as the proper subjects of justice. However, such strategies are notoriously problematic as they often serve to exclude many humans who also lack the relevant capacity, and attempts to identify a capacity possessed by all humans invariably result in some nonhuman animals qualifying for inclusion. ${ }^{39}$

This point is crucial for our discussion here. Cosmopolitans typically believe that the scope of justice covers all humans - not just rational individuals or those who posses the capacity for moral agency, but all humans irrespective of their abilities, natural endowments, and potential. Thus, the attempt to ground moral standing as a subject of justice in some capacity or set of capacities will likely be an unattractive option for the non-relational cosmopolitan because identifying an attribute possessed by all (and only) humans is a hopeless task, and few cosmopolitans will find the exclusion of infants and the cognitively impaired from the scope of justice acceptable. This seems especially true when we recall that cosmopolitans are motivated to protect the world's most vulnerable people, many of whom are children. Thus, to avoid the charge of speciesism and advance a theory that encompasses all human beings, the non-relational cosmopolitan must, in the absence of any further argument, reconceptualise the idea of the cosmopolitan individual to embody the needs and interests of all animals, rather than of just those who are genetically human. ${ }^{40}$

To sum up, neither relational nor non-relational cosmopolitans have obvious grounds for excluding all nonhuman animals from the scope of justice. For cosmopolitans to exclude nonhuman animals from the sphere of justice, they must deny that nonhuman animals also have lives that can go more or less well depending on whether their needs are met and interests protected, or they must argue that the well-being of nonhuman animals is insufficient to ground moral standing as a primary subject of justice. Either way, in light of the reasons I have presented here, cosmopolitans can no longer assume the primacy of humans over other animals and must justify the omission of the latter from their theorising.

39 For detailed critiques of such strategies, see Nathan Nobis, 'Carl Cohen's "Kind” Arguments for Animal Rights and Against Human Rights', Journal of Applied Philosophy 21/1 (2004), 43-59; Paola Cavalieri, The Animal Question: Why Nonhuman Animals Deserve Human Rights (New York: Oxford University Press, 2003); and Cochrane (2012), Chs. 2 and 3 .

40 To maintain, as I am, that species membership is not morally relevant from the perspective of cosmopolitan justice, is not to suggest that the various needs and interests of individual members of different species are irrelevant to questions of distribution. Indeed, what is needed for the lives of dogs to go well will vary from what is required to achieve well-being for parrots, chinchillas, cows or humans. However, by rejecting species membership as morally relevant to determining an entity's moral standing as a subject of justice, I am arguing that the like interests of humans and other animals should count as equally considerable from the perspective of justice. 


\section{The Capabilities Approach: A Cosmopolitan Solution?}

While few cosmopolitans acknowledge the existence of nonhuman animals, Martha Nussbaum explicitly attempts to extend the scope of justice to all animals in Frontiers of Justice: Disability, Nationality, Species Membership. ${ }^{41}$ In this section, I examine Nussbaum's account and argue that while the capabilities approach is promising, her particular view is inconsistent and exhibits a problematic anthropocentric bias. ${ }^{42}$

Nussbaum advocates a capability approach (CA) to social justice, which focuses on what people are able to do or, adopting the capability terminology, what kinds of functionings people are able to achieve. Nussbaum contends that her understanding of human capabilities is 'informed by an intuitive idea of a life that is worthy of the dignity of the human being, ${ }^{43}$ where human dignity can only be achieved when a human is able to live their life in a truly human way. That is, humans must have opportunities that allow them to function in ways that can be identified as truly human. Nussbaum then suggests that there are ten central capabilities essential to human dignity: (1) Life, (2) Bodily health, (3) Bodily integrity, (4) Senses, imagination and thought, (5) Emotions, (6) Practical reason, (7) Affiliation, (8) Other species, (9) Play and (10) Control over one's environment. ${ }^{44}$ When people lack any one of these central capabilities, their lives are no longer worthy of human dignity. Therefore, justice demands protecting and enabling human capabilities, and Nussbaum further suggests that human capabilities underpin political principles that should be the foundation of every nation-state's constitution. ${ }^{45}$

Despite her emphasis on human lives and human flourishing, Nussbaum recognises that many commonalities exist between humans and other animals and that we 'have many types of relationships with members of other species [...] relationships [that] ought to be regulated by justice, instead of the war for survival and power that now, for the most part, obtains.' ${ }^{46}$ Moreover, when

41 To see why Nussbaum's articulation of the capabilities approach is unmistakably cosmopolitan about distributive justice, consider the following. First, it is clear that the capabilities approach assumes all individuals to be the primary units of moral concern. Nussbaum states that 'the capabilities in question should be pursued for each and every person, treating each as an end and none as the mere tool of the ends of others' (Martha Nussbaum, Women and Human Development (Cambridge: Cambridge University Press 2000) p. 5, emphasis added) and that 'the capabilities approach remains focused on the person as the ultimate subject of justice' (2006, p. 295). Second, the capabilities approach specifies that individuals hold this status equally and that individuals are the primary units of moral concern for everyone (Nussbaum (2000), p. 74). It is also worth noting that Nussbaum's capabilities approach is a form of non-relational cosmopolitanism. Duties and entitlements of justice are not generated because particular relationships hold between individuals; rather, they obtain in virtue of the fact that all humans deserve to live lives worthy of human dignity. I would like to thank an anonymous referee for leading me to clarify this point.

42 My critique here is not intended as wholesale rejection of the capabilities approach but rather shows that Nussbaum's particular account is inadequate as a conception of sentience-based cosmopolitanism.

43 Nussbaum (2006), p. 70.

44 Martha Nussbaum (2000), pp. 78-80; 2006, 76-78.

45 Nussbaum (2006), p. 70.

46 Ibid., p. 326. 


\section{BEYOND ANTHROPOCENTRISM: COSMOPOLITANISM AND NONHUMAN ANIMALS}

extending CA to nonhuman animals, Nussbaum argues that they too are capable of living dignified lives and, thus, all animals possess central capabilities that must be protected to allow them to flourish as the beings that they are. She notes that the vast diversity in species will generate a plurality of speciesspecific capability lists because what is essential to the flourishing and dignity of whales, will be very different to that required to flourish as a bat ${ }^{47}$ Despite this, Nussbaum suggests that we might still use a general list, and she appeals to the central categories that, as I outlined above, she details for humans. ${ }^{48}$ Ultimately,

[...] [t]he general aim of the capabilities approach in charting political principles to shape the human-animal relationship [...] would be that no sentient animal should be cut off from the chance for a flourishing life, a life with the type of dignity relevant to that species, and that all sentient animals should enjoy certain positive opportunities to flourish. ${ }^{49}$

On the face of it, Nussbaum's position avoids the problems that I have identified with other cosmopolitan views; furthermore, she persuasively argues that the framework of capabilities can accommodate the needs and interests of nonhuman animals as a matter of justice. However, a deep conflict exists between her account of sentient animal capabilities and her conclusion that justice does not require a prohibition on the rearing and killing of animals for food..$^{0}$ To understand this tension, let us consider the nonhuman animal capability for life:

In the capabilities approach, all animals are entitled to continue their lives, whether or not they have such a conscious interest, unless and until pain and decrepitude make death no longer a harm. This entitlement is less robust when we are dealing with insects and other non-sentient or minimally sentient forms of life. [...] With sentient animals, things are different. All these animals have a secure entitlement against gratuitous killing for sport. Killing for luxury items such as fur falls in this category, and should be banned. So, too, should all cruel practices and painful killings in the process of raising animals for food. ${ }^{51}$

47 Ibid., 392-393.

48 Ibid., pp. 392-401.

49 Ibid., p. 351.

50 To be clear, I am not arguing that a cosmopolitan account of justice necessarily entails a prohibition on the killing of animals for food, though I do think that a suitably qualified version of that claim can be defended. My point is rather that Nussbaum's view entails this conclusion, and her resistance to it reveals that she does not genuinely include nonhuman animals as equals within her cosmopolitan framework.

51 Nussbaum (2006), p. 393, emphasis added. 
Here, we see that Nussbaum believes that nonhuman animals have an interest in continued existence and thus says that they are 'entitled to continue their lives.' ${ }^{2}$ She argues that the capability for life demands a prohibition on the gratuitous killing of nonhuman animals and a ban on the cruel practices associated with the meat and dairy industries. However, in a puzzling move, she stops short of a prohibition on the rearing and killing of animals for food. Yet, if nonhuman animals are entitled, as a matter of justice, to be well treated by humans and not have their lives prematurely ended to satisfy gratuitous human ends, then Nussbaum's suggestion that justice does not require a prohibition on the rearing of animals for food is deeply problematic. ${ }^{53}$

Although Nussbaum calls for a ban on the cruel practices involved in factory farming, she is reluctant to call for a similar prohibition on the painless killing of nonhuman animals for food when they have had the opportunity to flourish and lead dignified lives. However, given that in her view nonhuman animals have an interest in their continued existence, whether they have the opportunity to flourish should be irrelevant; they have an interest in continuing to exist, and thus, premature death harms them. ${ }^{54}$ This is particularly problematic when we recall that Nussbaum explicitly argues for a prohibition on the gratuitous killing of animals. As Gary Francione has argued extensively, for most humans the 'only justification for the pain, suffering, and death inflicted on [...] billions of nonhuman animals is that we enjoy the taste of their flesh and other animal products. 55 Taste must surely be considered a non-essential and trivial human interest, and the annual killing of billions of nonhuman animals to satisfy human taste cannot be viewed as anything other than gratuitous killing. ${ }^{56}$ Thus, justice, by Nussbaum's own lights, must require a prohibition on the rearing and killing of animals for food.

52 On this point I, and many others, agree with Nussbaum. In support of this idea, one might argue that even painless death is harmful to creatures with the capacity for well-being and flourishing insofar as it closes the door on all opportunities for living well or the capability to flourish. Thus, nonhuman animals have an interest in continuing to exist so that they may have the opportunity to live flourishing lives (Nussbaum (2006), pp. 385-388; see also Cochrane (2012), p. 65). Nonetheless, I cannot give a thorough defence of the claim that animals have an interest in continued existence here.

53 Nussbaum (2006), p. 393.

54 An anonymous reviewer suggested that Nussbaum is more concerned with the wrongs of factory farming because her CA is primarily concerned with dignity - not well-being - and thus while some ways of rearing and killing animals may be compatible with their living a dignified life, factory farming is not one of those ways. In response, I think it worth pointing out that although Nussbaum is clearly concerned with the dignity of individual sentient animals, she says of her CA that '[...] its focus is on the well-being of existing creatures, and the harm that is done to them when their powers are blighted' (2006, p. 357 emphasis added). I interpret this to suggest that as dignity is only a part of the picture, killing animals for food, even while preserving their dignity (if such a thing is possible), involves a serious wrong to the animals since they are no longer capable of exercising their capabilities for a flourishing life.

55 Gary L. Francione, Animals as Persons: Essays on The Abolition of Animal Exploitation (New York: Columbia University Press, 2008), p. 172.

56 One might try to argue that meat is an essential component of the human diet without which human health would suffer. Little scientific evidence supports this claim and it is undermined by the fact that many humans lead healthy lives on plant-based diets. 


\section{BEYOND ANTHROPOCENTRISM: COSMOPOLITANISM AND NONHUMAN ANIMALS}

Nussbaum may have some sympathy with this conclusion, but is likely to respond that because $\mathrm{CA}$ is a political conception of liberal justice, it could not legitimately prohibit the killing of animals for meat. ${ }^{57}$ That is, CA must remain neutral between competing conceptions of the good so that it can be the subject of an overlapping consensus constituted by a majority of reasonable citizens. Moreover, this commitment to political liberalism entails that CA must be constructed from ideas taken from the shared public political culture comprising 'the political institutions of a constitutional regime and the public traditions of their interpretation (including the judiciary), as well historic texts and documents that are common knowledge.' 58

As meat-eating is important to many and varied conceptions of the good, a conception of justice that prohibited the eating of nonhuman animals could not be the focus of an overlapping consensus. ${ }^{59}$ This is partly because meat consumption is widely deemed acceptable, and the moral worth of animals, if they are considered to have moral worth at all, is generally regarded to be considerably lower than that of humans. More importantly, the 'idea of crossspecies dignity is not a political idea that can readily be accepted by citizens who otherwise differ in metaphysical conception. It is a divisive metaphysical idea, in contradiction with many religious ideas of the soul, and so forth. ${ }^{60}$ Thus, any conception of justice that appeals to the idea of equal dignity across species relies on a disputed metaphysical claim and is not purely political in the way necessary to achieve an overlapping consensus.

We are now in a position to see why, despite the bold statement that 'all animals are entitled to continue their lives,' Nussbaum appears to backpedal by denying that the non-essential human consumption of meat ought to be prohibited as a requirement of justice. For Nussbaum, such a move could only be justified if the belief that all species are equal in dignity were established in the shared public political culture; however, as it is not, we are left only with the 'divisive metaphysical' idea. Nevertheless, even though humans and other animals are unequal in dignity, for Nussbaum, justice requires us to strive to provide each nonhuman animal with adequate opportunity to flourish as is appropriate for members of their species. ${ }^{61}$

However, Nussbaum's concession to our current culture of meat consumption is deeply troubling because it suggests that wrongs can only be prohibited when the majority regards the matter in question as wrong. Yet, one only has to think

57 Nussbaum (2006), p. 388.

58 John Rawls, Political Liberalism (expanded edition) (New York: Columbia University Press, 2005), p. 13.

59 Nussbaum (2006), p. 390.

60 Ibid., p. 384.

61 Ibid., p. 384 . 
of the many historical injustices that have befallen certain groups to see that this thought is problematic. If, for example, dominant social and religious attitudes maintain that women are not entitled to equal property rights, equal rights to divorce, and the right to vote, then it would appear to follow that women are not entitled to these rights as a matter of justice. However, much of Nussbaum's work on women and global justice resolutely resists this conclusion because, regardless of where a woman is born, she is entitled to be considered a fully equal person in both standing and rights. ${ }^{62}$ Perhaps Nussbaum would reply that women are entitled to equal political liberties precisely because equal human dignity is not a metaphysical idea but a purely political idea that transcends national boundaries. But what reason do we have to think that the idea of equal human dignity is any less 'metaphysically divisive' than the idea of equal dignity across species? In an excellent critique, Cécile Fabre and David Miller note several ways in which the list of capabilities that Nussbaum advances is not purely political:

[...] Nussbaum tells us that we should all have 'opportunities for sexual satisfaction and for choice in matters of reproduction' [Women and Human Development, p. 78]: in the context of her book, this particularly applies to women. Whether or not that claim is true, it is clear that it must involve denying, contrary to what many people think, that God has allocated women the task of reproduction. To take the issue even further, if (as one might reasonably surmise) having reproductive choice means, for Nussbaum, having access to reliable contraception (perhaps, even, to abortion), this particular capability presupposes a certain relationship between mind and body (and, in the case of abortion, confers a status on the embryo) with which many people would take issue. More generally and fundamentally still, her account rests on the central assumption that individuals are autonomous beings, capable of shaping their own destiny. This in turn rests on a set of metaphysical presuppositions about what a person is, whether or not a person has free will, whether or not there is a God who determines the course of her life, etc. ${ }^{63}$

Given that the constitutive elements of a life worthy of human dignity are contested, it seems probable that the very idea of equal human dignity will be disputed - especially in a world where many humans consider others with

62 Martha Nussbaum, 'Women and Theories of Global Justice: Our Need for New Paradigms' in D. K. Chatterjee (ed.), The Ethics of Assistance: Morality and the Distant Needy (Cambridge: Cambridge University Press, 2004), pp. 147-176.

63 Cecile Fabre and David Miller, 'Justice and Culture: Rawls, Sen, Nussbaum and O’Neill', Political Studies Review 1/1 (2003), 4-17, p. 8. 


\section{BEYOND ANTHROPOCENTRISM: COSMOPOLITANISM AND NONHUMAN ANIMALS}

different national, religious, ethnic, sexual or gender identities to have less moral worth. If this is the case, then we have no more reason to exclude the idea of equal dignity across species as metaphysically divisive than we do to exclude that of the equal dignity of humans.

Moreover, it is difficult to see how Nussbaum can allow the rearing and killing of animals for food while simultaneously calling for an end to the gratuitous killing of nonhuman animals for sport. ${ }^{64}$ If equal dignity across species is a metaphysical idea and justice does not require the gratuitous killing of nonhuman animals for food to be prohibited, then on what politically liberal grounds is some gratuitous killing acceptable and some not? Basically Nussbaum is keen to avoid conflict with dominant conceptions of the good and social attitudes that are currently pervasive. Therefore, while she suggests that we must end blood sports like bullfighting, bear baiting, and dog fighting presumably because she believes these activities enjoy little support - other cruel practices are permissible. However, as Gary Steiner's careful reading of Nussbaum's account shows, CA

[...] does not prohibit us from using [nonhuman animals] in various forms of entertainment such as horse racing; it does not prohibit us from killing them (painlessly, of course) to provide food for other humans; it does not prohibit us from experimenting on animals (as long as we seek to 'improve the lives of research animals'); and it by no means requires us to decry any practice that harms animals as it is undertaken in the name of religion. ${ }^{65}$

Thus, for Steiner, despite Nussbaum's initial claim that nonhuman animals are to be considered the proper subjects of justice, 'animals are not genuinely recognised to be subjects but instead remain instrumentalities for the satisfaction of human needs. ${ }^{66}$

Ultimately, Nussbaum's cosmopolitanism does not adequately accommodate the interests of nonhuman animals because, despite its initial promise, it gives ultimate superiority to human interests and wants, irrespective of whether or not they can be morally justified. If Nussbaum is genuinely committed to the idea that nonhuman animals are the proper subjects of justice, that they have justice-based entitlements, and that the 'cruel and oppressive treatment of animals raises questions of justice,' then she must make animals as central to our thinking about justice as humans are. ${ }^{67}$ Thus, a suitably revised version of

64 Gary Steiner, 'Toward a Non-Anthropocentric Cosmopolitanism' in R. Boddice (ed.), Anthropocentrism: Humans, Animals, Environments (Leiden, The Netherlands: Brill, 2011), p. 103.

65 Ibid., p. 104.

66 Ibid., p. 104.

67 Nussbaum (2006), pp. 235-236. 
CA would take all animals, human or otherwise, as the primary units of moral concern and would require us to embrace fully the idea that equal animal dignity applies across species and not only to humans.

\section{Conclusion}

In this paper, I have argued that cosmopolitans can no longer assume that humans are the only primary units of moral concern in considerations of global distributive justice. My principal aim has been to demonstrate that, even by their own lights cosmopolitans have good reason to extend the scope of justice to encompass a very significant number of, if not all, nonhuman animals. While cosmopolitans may disagree with me on this point, the burden now lies with them to offer adequate justification for the exclusion of nonhuman animals from their accounts. ${ }^{68}$

Angie Pepper

Queen's University

Email:angie.pepper@queensu.ca

\section{the global justicenetwork}

68 Many thanks to Alasdair Cochrane, Sue Donaldson, Rich Healey, Will Kymlicka, Jimmy Lenman, David O’Brien and two anonymous referees of this journal for their constructive written feedback at various stages of the writing process. I also thank the audience and participants at the MANCEPT panel on 'Global Injustice - Radical Perspectives' (University of Manchester, 2014). 